\title{
ARTICLE
}

Received 30 Jan 2014 | Accepted 24 Oct 2014 | Published 5 Dec 2014 DOl: 10.1038/ncomms6663

\section{Isotopic constraints on biogeochemical cycling of copper in the ocean}

\author{
Shotaro Takano ${ }^{1}$, Masaharu Tanimizu², Takafumi Hirata ${ }^{3} \&$ Yoshiki Sohrin ${ }^{1}$
}

Trace elements and their isotopes are being actively studied as powerful tracers in the modern ocean and as proxies for the palaeocean. Although distributions and fractionations have been reported for stable isotopes of dissolved $\mathrm{Fe}, \mathrm{Cu}, \mathrm{Zn}$ and $\mathrm{Cd}$ in the ocean, the data remain limited and only preliminary explanations have been given. Copper is of great interest because it is either essential or toxic to organisms and because its distribution reflects both biological recycling and scavenging. Here we present new isotopic composition data for dissolved $\mathrm{Cu}\left(\delta^{65} \mathrm{Cu}\right)$ in seawater and rainwater. The $\mathrm{Cu}$ isotopic composition in surface seawater can be explained by the mixing of rain, river and deep seawater. In deep seawater, ${ }^{65} \mathrm{Cu}$ becomes heavier with oceanic circulation because of preferential scavenging of the lighter isotope $\left({ }^{63} \mathrm{Cu}\right)$. In addition, we constrain the marine biogeochemical cycling of $\mathrm{Cu}$ using a new box model based on $\mathrm{Cu}$ concentrations and $\delta^{65} \mathrm{Cu}$.

\footnotetext{
${ }^{1}$ Institute for Chemical Research, Kyoto University, Kyoto 611-0011, Japan. ${ }^{2}$ Kochi Institute for Core Sample Research, Japan Agency for Marine-Earth Science and Technology, 200 Monobe Otsu, Nankoku 783-8502, Japan. ${ }^{3}$ Laboratory for Planetary Sciences, Division of Earth and Planetary Sciences, Kyoto University, Kitashirakawa Oiwake-cho, Kyoto 606-8502, Japan. Correspondence and requests for materials should be addressed to S.T. (email: shotaro@inter3.kuicr.kyoto-u.ac.jp).
} 
C opper plays an important role as a micronutrient for organisms in the ocean, but high concentrations of the free $\mathrm{Cu}^{2+}$ ion are toxic ${ }^{1}$. Dissolved $\mathrm{Cu}$ has concentrations of $0.5-6 \mathrm{nmol} \mathrm{kg}^{-1}$ in seawater and mostly complexes with organic ligands, which results in very low concentrations $\left(\mathrm{fmol} \mathrm{kg}-1\right.$ to $\mathrm{pmol} \mathrm{kg}^{-1}$ ) of the free $\mathrm{Cu}^{2+}$ ion $^{2}$. Vertical distributions of dissolved $\mathrm{Cu}$ are of the nutrient-scavenging hybrid type ${ }^{3}$. Generally, the concentrations of nutrient-type trace metals (for example, $\mathrm{Zn}, \mathrm{Ni}$ and $\mathrm{Cd}$ ) are low in the surface layer of the ocean because of biological uptake. However, the concentrations increase with depth, showing a mid-depth maximum because of remineralization from settling particles. By contrast, the concentration of dissolved $\mathrm{Cu}$ gradually increases with depth to the bottom. Such distributions have been interpreted to be caused by a combination of scavenging throughout the water column and a supply from the uppermost layer of benthic sediments, where scavenged $\mathrm{Cu}$ is recycled to overlying seawater via early diagenesis ${ }^{4,5}$. Copper has two stable isotopes, ${ }^{63} \mathrm{Cu}$ and ${ }^{65} \mathrm{Cu}$, and its isotopic composition is reported as $\delta^{65} \mathrm{Cu}(\%)=\left[\left({ }^{65} \mathrm{Cu} /{ }^{63} \mathrm{Cu}\right)_{\text {sample }} /\left({ }^{65} \mathrm{Cu} /{ }^{63} \mathrm{Cu}\right)_{\text {NIST }}\right.$ SRM $\left.976-1\right]$ $\times 10^{3}$. To date, only a few vertical profiles of dissolved $\delta^{65} \mathrm{Cu}$ in the ocean have been reported ${ }^{6-9}$. The reported $\delta^{65} \mathrm{Cu}$ values $(0.44-1.44 \%$ ) were substantially heavier than typical values for the solid Earth $(\sim 0 \%)^{10,11}$. However, as there are relatively large uncertainties in the reported data, it has been difficult to elucidate intra-ocean distributions. This is partly due to analytical difficulties in the determination of $\delta^{65} \mathrm{Cu}$ caused by the interference of matrices and the inapplicability of the so-called double-spike technique.

Recently, we developed a simple and precise analytical method for $\delta^{65} \mathrm{Cu}$ based on a chelating resin extraction technique ${ }^{12}$. Here we use this method to present new isotopic data of compositions of dissolved $\mathrm{Cu}\left(\delta^{65} \mathrm{Cu}\right)$ in seawater from the North and South Atlantic, South Indian and North Pacific oceans. We also present new data from rainwater samples collected from urban and rural regions. Using these data, the $\mathrm{Cu}$ isotopic composition in surface seawater is explained in an oceanographic context. In deep seawater, $\delta^{65} \mathrm{Cu}$ values show a linear correlation with apparent oxygen utilization (AOU), which suggests $\delta^{65} \mathrm{Cu}$ becomes heavier with oceanic circulation because of preferential scavenging of the lighter isotope $\left({ }^{63} \mathrm{Cu}\right)$. Our data show that the stable isotopic values of trace metals may change systematically with the age of deep water. In addition, we propose a new box model for $\mathrm{Cu}$ in the ocean based on the combination of $\mathrm{Cu}$ concentration and $\delta^{65} \mathrm{Cu}$, constraining the marine biological cycling of $\mathrm{Cu}$.

\section{Results}

Seawater analyses. The observed oceanic stations are shown in Fig. 1. All seawater data are summarized in Supplementary Table 1. The vertical profiles of dissolved $\mathrm{Cu}$ concentration and $\delta^{65} \mathrm{Cu}$ for each station are presented in Supplementary Fig. 1, and representative profiles are shown in Fig. 2. The $\mathrm{Cu}$ concentrations were in the range of $0.6-4.6 \mathrm{nmol} \mathrm{kg}^{-1}$, and the profile at station ER10 agreed well with that determined in separate samples collected at the same station in our previous research (Supplementary Fig. 2) ${ }^{14}$. The $\delta^{65} \mathrm{Cu}$ values ranged from $+0.41 \%$ to $+0.85 \%$, which was lighter than values determined by a $\mathrm{Mg}(\mathrm{OH})_{2}$ co-precipitation technique $(+0.50$ to $1.44 \%$ o $)^{7,8}$ at other stations and similar to values determined by a solvent extraction technique $(+0.44 \text { to } 0.78 \% \text { o })^{6,9}$ at other stations (Supplementary Fig. 3). The vertical samples from the GEOTRACES Atlantic intercalibration station (Bermuda Atlantic Time-series Study, BATS) have been analysed using a solvent extraction technique by Thompson et al. ${ }^{9}$ The reported $\delta^{65} \mathrm{Cu}$ value $(0.56 \pm 0.09 \%$ ) for a 2,000 -m depth sample was higher than our value $(0.41 \pm 0.05 \%$ ). Unfortunately, we are not able to investigate the causes because the BATS samples have been exhausted. Recently, we performed an intercalibration of $\delta^{65} \mathrm{Cu}$ with a group from ETH, Zurich (see Acknowledgements section for details), using seawater collected at a station near the Japan Trench, of which details are described in the Supplementary Methods. The ETH group used a new method based on $\mathrm{Al}(\mathrm{OH})_{3}$ co-precipitation ${ }^{15}$, which gave results consistent with ours (Supplementary Fig. 4).

The vertical profiles of $\delta^{65} \mathrm{Cu}$ in this work showed a common feature: $\delta^{65} \mathrm{Cu}$ was $\sim 0.5 \%$ in the surface layer and became heavier at depth. Station BD21 above the Juan de Fuca Ridge had a minimum $\mathrm{Cu}$ concentration at a depth of $2,300 \mathrm{~m}$, reflecting the effect of a hydrothermal plume ${ }^{16}$. There were, however, no significant variations in $\delta^{65} \mathrm{Cu}$.

Rainwater analyses. We also determined $\delta^{65} \mathrm{Cu}$ in rainwater for the first time (Table 1). Rainwater was sampled from rural and urban regions in Japan. The dissolved $\delta^{65} \mathrm{Cu}$ values were in the narrow range of -0.12 to $+0.03 \%$ and did not show significant differences depending on location and time, whereas the $\mathrm{Cu}$ concentrations varied largely $\left(1.1-23.5 \mathrm{nmol} \mathrm{kg}^{-1}\right)$, which may reflect various contributions of anthropogenic input. It has been reported that $\delta^{65} \mathrm{Cu}$ values were $\sim 0 \%$ for leachable fractions of marine aerosols ${ }^{11}$ and bulk loess ${ }^{17}$. Rainwater would scavenge both atmospheric dusts and anthropogenic aerosols during precipitation. Therefore, it seems reasonable to presume the $\delta^{65} \mathrm{Cu}$ value for atmospheric input to be zero.

Copper isotopes in surface seawater. In Fig. 3, the $\delta^{65} \mathrm{Cu}$ in surface seawater is plotted against the reciprocal $\mathrm{Cu}$ concentration together with the ranges and averages of deep seawater, rural rainwater and river water ${ }^{8}$. Assuming that average surface seawater is a mixture of average rural rainwater, average river water and average deep seawater, the plot would be located in the magenta triangle. Evaporation that is another important factor to control salinity; it would increase the $\mathrm{Cu}$ concentration but not change the $\delta^{65} \mathrm{Cu}$. However, the surface water data are shifted to the right of the triangle, indicating there must be other processes that decrease the dissolved $\mathrm{Cu}$ concentration (up to one tenths) while keeping the $\delta^{65} \mathrm{Cu}$ values constant. The most likely process is phytoplankton uptake and adsorption of $\mathrm{Cu}$ onto the phytoplankton surface. It is well known that these processes produce biogenic sinking particles in the surface layer and they transport trace metals to the deep layer. Our data suggest that uptake and adsorption by phytoplankton in the open ocean does not cause significant fractionation of $\mathrm{Cu}$ isotopes. To clarify

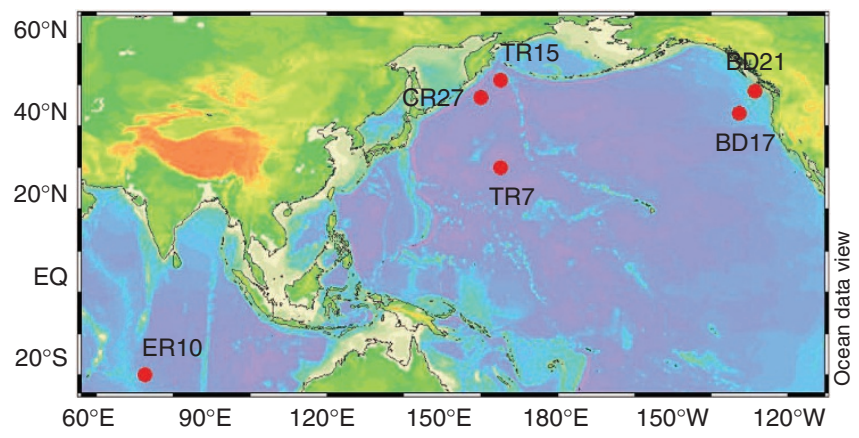

Figure 1 | Station locations. Samples for the analysis of $\delta^{65} \mathrm{Cu}$ were collected at these stations during R/V Hakuho-maru cruises. The numbers of samples are 10 at TR7, 10 at TR15, 10 at CR27, 14 at BD17, 12 at BD21 and 18 at ER10. This figure was produced using Ocean Data View ${ }^{13}$. 
Central S. Indian, ER10
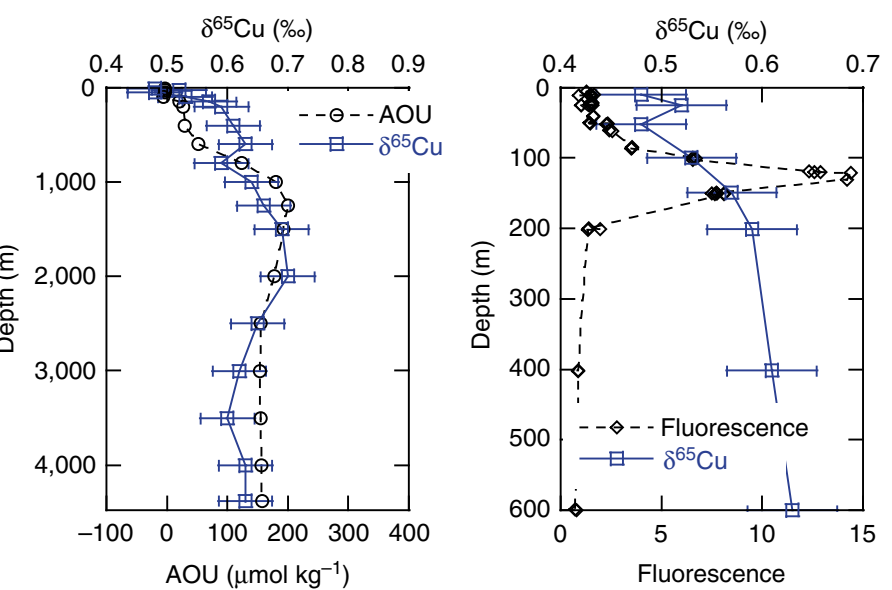

Western N. Pacific, TR7
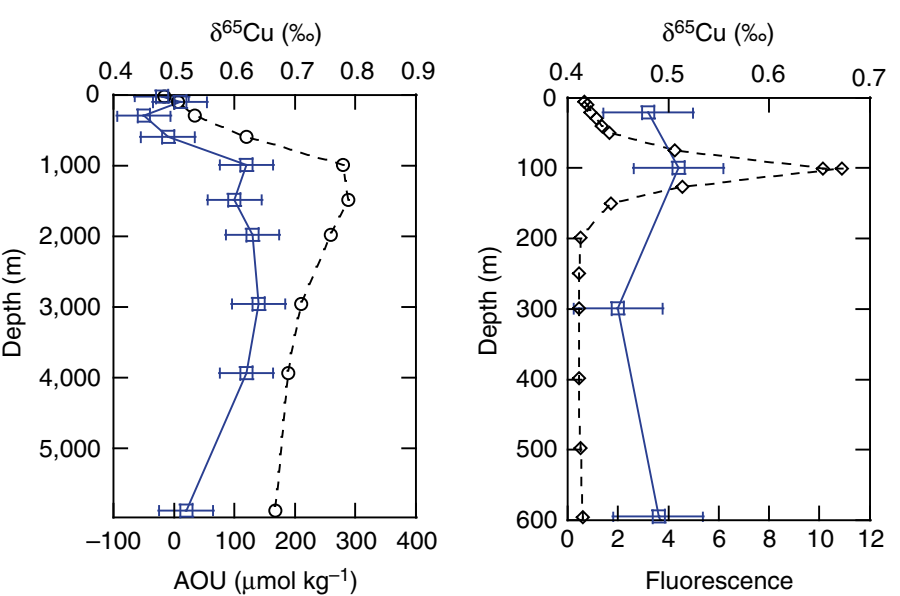

Eastern N. Pacific, BD17
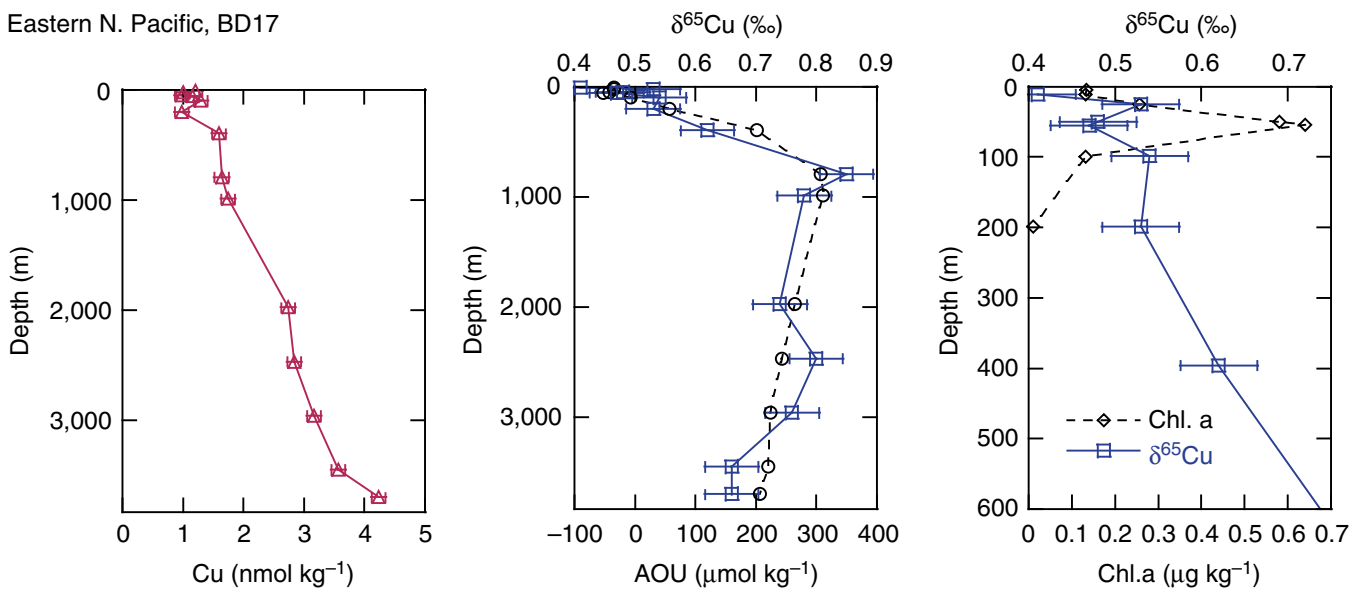

Figure 2 | Representative vertical profiles of the concentration and isotopic composition of Cu. Magenta triangles indicate $\mathrm{Cu}$ concentration. Blue squares and black circles indicate $\delta^{65} \mathrm{Cu}$ and apparent oxygen utilization (AOU), respectively. Black diamonds indicate fluorescence or chlorophyll a (Chl. a). The error bars are 2 s.d. of $\pm 0.045 \%$ for $\delta^{65} \mathrm{Cu}$ and $\pm 0.11 \mathrm{nmol} \mathrm{kg}{ }^{-1}$ for $\mathrm{Cu}$ concentration, as described in the Methods section.

The vertical profiles at all stations are shown in Supplementary Fig. 1.

mechanisms controlling the $\mathrm{Cu}$ concentration and $\delta^{65} \mathrm{Cu}$, it is informative to compare $\mathrm{Cu}$ and $\mathrm{Cd}$ in the ocean. For vertical profiles of dissolved $\mathrm{Cd}$, the isotopic ratio $\left(\varepsilon^{114} \mathrm{Cd}\right)$ correspondingly increases with a decrease in the concentration in the surface layer and decreases with an increase in the concentration from the surface to the intermediate layer, because biological uptake causes isotopic fractionation of $\mathrm{Cd}^{18-20}$. Therefore, the profile of $\varepsilon^{114} \mathrm{Cd}$ from the surface to the intermediate layer becomes a mirror image of the concentration, and $\varepsilon^{114} \mathrm{Cd}$ linearly correlates with the logarithm concentration in the surface layer because of Rayleigh fractionation during biological uptake ${ }^{18-21}$. However, $\delta^{65} \mathrm{Cu}$ does not change correspondingly to the $\mathrm{Cu}$ concentration from the surface to the intermediate layer (Fig. 2 and Supplementary Fig. 1), and does not correlate with the logarithmic concentration in the surface layer (Supplementary Fig. 5). These facts also indicate biological processes cause insignificant fractionation of the $\mathrm{Cu}$ isotopes. 
Copper isotopes in deep seawater. Given that uptake and adsorption of $\mathrm{Cu}$ by phytoplankton does not cause fractionation of $\mathrm{Cu}$ isotopes, biogenic sinking particles would have the same

Table 1 | Rainwater analysis results.

\begin{tabular}{|c|c|c|c|}
\hline Sample $^{\star}$ & Date & $\mathrm{Cu}\left(\mathrm{nmol} \mathrm{kg}{ }^{-1}\right)$ & $\delta^{65} \mathrm{Cu}$ \\
\hline Urban-1 & 20 June 2013 & 1.51 & -0.08 \\
\hline Urban-2 & 26 June 2013 & 1.84 & 0.03 \\
\hline Urban-3 & 3 July 2013 & 23.46 & -0.12 \\
\hline Rural-1 & 19-21 June 2013 & 1.12 & -0.03 \\
\hline Rural-1 & 19-21 June 2013 & 1.14 & -0.01 \\
\hline Rural-2 & 4-7 July 2013 & 2.60 & 0.03 \\
\hline
\end{tabular}

*'Urban' samples were collected on the roof of the main building of the Uji campus on Honshu Island, Japan. 'Rural' samples were collected at the top of Mt. Kajigamori on Shikoku Island, Japan.

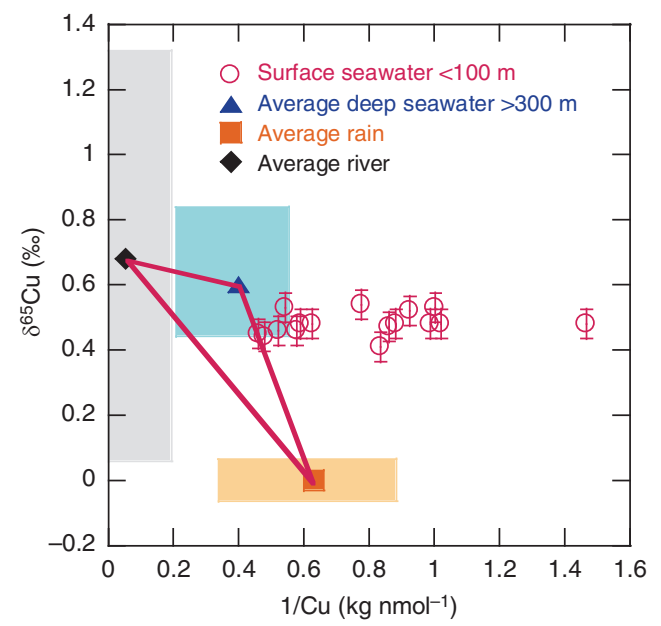

Figure $3 \mid \delta^{65} \mathrm{Cu}$ vs reciprocal $\mathrm{Cu}$ concentration for surface seawater $(<\mathbf{1 0 0} \mathbf{~ m})$. The error bars of the magenta circles are 2 s.d. of $\pm 0.045 \%$. The blue, black and orange shaded areas indicate the ranges of the data for deep seawater, river water and rural rain, respectively. The magenta triangle indicates the possible range of mixtures of average deep seawater, river water and rainwater. The surface water data shifted to the right of the triangle indicate that other processes decrease the dissolved $\mathrm{Cu}$ concentration in the surface seawater. $\delta^{65} \mathrm{Cu}$ value as surface seawater. Copper regenerated through decomposition of the biogenic sinking particles should produce $\delta^{65} \mathrm{Cu}$ values in deep seawater, which are the same as those in surface seawater under this assumption. However, observed $\delta^{65} \mathrm{Cu}$ in deep seawater is heavier than that in surface seawater. In addition, the profiles of $\delta^{65} \mathrm{Cu}$ are similar to those of AOU (Fig. 2 and Supplementary Fig. 1). All $\delta^{65} \mathrm{Cu}$ values are plotted against AOU, revealing a positive correlation $\left(R^{2}=0.60, n=77\right.$; Fig. $\left.4 \mathrm{a}\right)$. In the layer deeper than $2,000 \mathrm{~m}, \delta^{65} \mathrm{Cu}$ vs AOU shows a stronger correlation $\left(R^{2}=0.70, n=25\right.$; Fig. $\left.4 \mathrm{~b}\right)$. Because AOU is a measure of the age of deep water, these data imply that $\delta^{65} \mathrm{Cu}$ increases through deep water circulation. When the $\mathrm{Cu}$ concentration is plotted against AOU, there is also a weak correlation $\left(R^{2}=0.31, n=77\right.$, Fig. 5).

In the case of $\mathrm{Cd}$, the dissolved concentration is very low $\left(\sim 0.001 \mathrm{nmol} \mathrm{kg}^{-1}\right)$ in the surface layer because of biological uptake, and it is high in the deep layer $\left(\sim 1 \mathrm{nmol} \mathrm{kg}^{-1}\right)$ because of remineralization from biogenic particles; it also increases along the global deep circulation ${ }^{3}$. Because there is a significant correlation between $\mathrm{Cd}$ and phosphate, the distribution of $\mathrm{Cd}$ is dominated by biogeochemical recycling. The isotopic composition of $\mathrm{Cd}$ is heavier in surface seawater $\left(\varepsilon^{114 / 110}\right.$ $\mathrm{Cd}=10-40$ with respect to the JMC Cd Münster solution) than in deep seawater $\left(\varepsilon^{114 / 110} \mathrm{Cd}=\sim 3\right)$ that is almost uniform in the world ocean ${ }^{18-20}$. Biological uptake depletes the Cd concentration and preferentially leaves isotopically heavy $\mathrm{Cd}$ in surface seawater. It is suggested that $\mathrm{Cd}$ in a replenished surface seawater reservoir is originally characterized by $\varepsilon^{114 /}$ ${ }^{110} \mathrm{Cd}=\sim 3$ and that this $\mathrm{Cd}$ is almost quantitatively transported by biogenic sinking particles from the surface to depth and remineralized in deep water; thus, the $\mathrm{Cd}$ isotopic composition of deep water is homogeneous, whereas the $\mathrm{Cd}$ concentration increases along with deep water circulation.

The $\delta^{65} \mathrm{Cu}$ in deep seawater appears to be controlled by a ubiquitous effect throughout the water column and deep water pathway because $\delta^{65} \mathrm{Cu}$ correlates with AOU. Copper is more strongly scavenged than other recycled-type trace metals such as $\mathrm{Cd}^{3,5}$. The scavenging is likely the reason that $\delta^{65} \mathrm{Cu}$ is heavy in the deep layer and becomes heavier with the age of deep seawater. If this is true, ${ }^{63} \mathrm{Cu}$ would be preferentially adsorbed to sinking particles and preserved in sinks. The low linearity of $\mathrm{Cu}$ concentration against AOU (Fig. 5) would be due to the combination of scavenging throughout the water column and supply from sediments through decomposition of the organic fraction of sinking particles. The $\mathrm{Cu}$ released from sediments
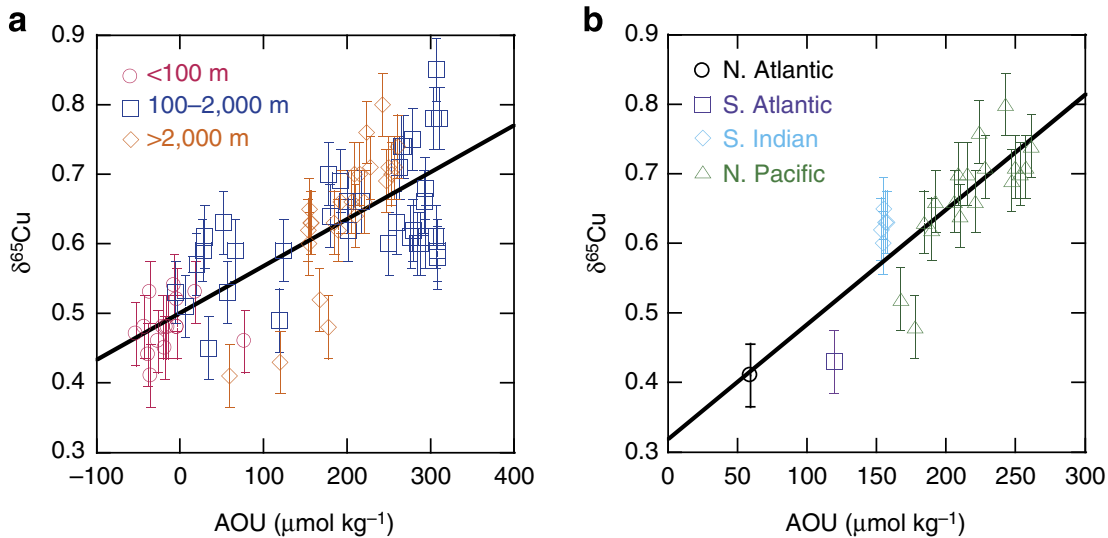

Figure $4 \mid \delta^{65} \mathrm{Cu}$ vs AOU for seawater. The error bars for $\delta^{65} \mathrm{Cu}$ are 2 s.d. of $\pm 0.045 \%$. (a) All $\delta^{65} \mathrm{Cu}$ values were plotted against apparent oxygen utilization (AOU). The solid line was determined by a regression analysis of all plots: $\delta^{65} \mathrm{Cu}=0.00067 \times \mathrm{AOU}+0.50, R^{2}=0.60, n=77, P<0.001$. (b) $\delta^{65} \mathrm{Cu}$ values were plotted against $\mathrm{AOU}$ in deep seawater $(>2,000 \mathrm{~m})$. The solid line was determined by a regression analysis of all plots: $\delta^{65} \mathrm{Cu}=0.0016 \times \mathrm{AOU}+0.32, R^{2}=0.70, n=25, P<0.001$. 


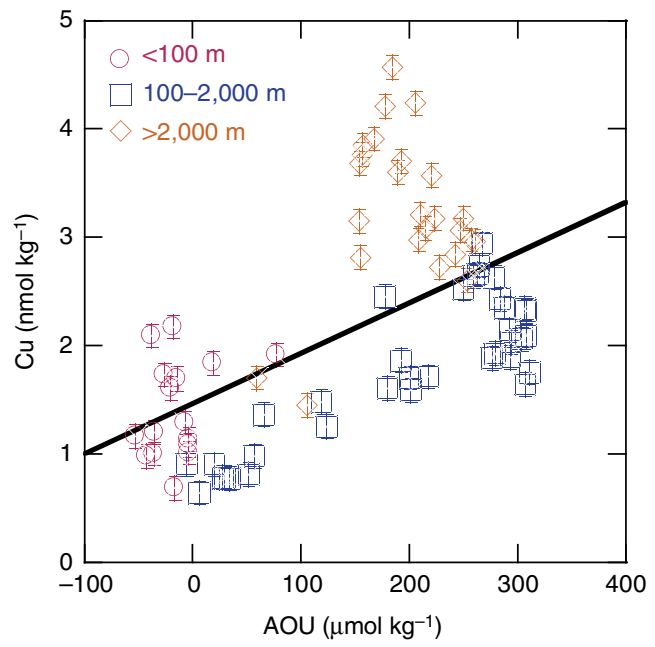

Figure 5 | $\mathbf{C u}$ concentration vs $\mathbf{A O U}$ in the ocean. The error bars are 2 s.d. of $\pm 0.11 \mathrm{nmol} \mathrm{kg}^{-1}$. The solid line was defined as: $[\mathrm{Cu}]=0.0046 \times \mathrm{AOU}+1.5, R^{2}=0.31, n=77, P<0.001$.

most likely has a $\delta^{65} \mathrm{Cu}$ value similar to that in seawater near the bottom, resulting in the linearity of $\delta^{65} \mathrm{Cu}$ vs AOU.

Box model for $\mathrm{Cu}$ in the modern ocean. We present a new box model for $\mathrm{Cu}$ based on both concentration and isotopic composition (Fig. 6 and Supplementary Table 2). This model assumes a steady state for the modern ocean. In this model, the global ocean is divided simply into a euphotic layer and a deep layer at a depth of $100 \mathrm{~m}$. A thin layer on the sediment surface is considered as the box of the 'scavenged layer', where organic matter is decomposed during early diagenesis ${ }^{22}$. In Fig. 6 , the black figures are observed or previously published values, as described below. Magenta figures are values calculated using the following equations ${ }^{11}$, which assumes a steady state for each box:

$$
\begin{gathered}
\Sigma F_{\text {in }}=\Sigma F_{\text {out }} \\
\Sigma F_{\text {in }} \delta_{\text {in }}=\Sigma F_{\text {out }} \delta_{\text {out }}
\end{gathered}
$$

where $F_{\text {in }}$ and $F_{\text {out }}$ represent an input and output flux for the box, and $\delta_{\text {in }}$ and $\delta_{\text {out }}$ represent $\delta^{65} \mathrm{Cu}$ values of $F_{\text {in }}$ and $F_{\text {out }}$, respectively. Based on this work, the depth-weighted averages of $\mathrm{Cu}$ concentration and $\delta^{65} \mathrm{Cu}$ are $1.1 \mathrm{nmol} \mathrm{kg}^{-1}$ and $0.49 \%$ in surface seawater and $2.5 \mathrm{nmol} \mathrm{kg}^{-1}$ and $0.60 \%$ in deep seawater, respectively. The water mixing rate between the upper box and lower box is assumed to be $1.2 \times 10^{15} \mathrm{~m}^{3} \mathrm{yr}^{-1}$, which has been determined from ${ }^{14} \mathrm{C}$ data ${ }^{23}$. We assumed that the main inputs of dissolved $\mathrm{Cu}$ to the ocean are riverine and atmospheric inputs. The reported riverine input of dissolved $\mathrm{Cu}$ to the ocean among four studies ${ }^{4,8,24,25}$ was in the range of $6-9 \times 10^{8} \mathrm{~mol} \mathrm{yr}^{-1}$, and the average value of $7.6 \times 10^{8} \mathrm{~mol} \mathrm{yr}^{-1}$ was applied to our model. The removal rate of dissolved $\mathrm{Cu}$ from the ocean was estimated to be $\sim 4.0 \mathrm{nmol} \mathrm{kg}^{-1} \mathrm{yr}^{-1}$ by using a vertical advection diffusion model $^{4,5}$. By multiplying this value by the total ocean volume $\left(1.35 \times 10^{21} \mathrm{~kg}\right)$, the scavenging flux of $\mathrm{Cu}$ in the ocean was estimated to be $5.4 \times 10^{9} \mathrm{~mol} \mathrm{yr}^{-1}$. Riverine input $\delta^{65} \mathrm{Cu}$ was determined in rivers worldwide; the rivers account for approximately one-quarter of all riverine discharge to the ocean $^{8}$. The discharge-weighted average of $0.68 \%$ of these rivers was used in our model. The $\delta^{65} \mathrm{Cu}$ of atmospheric input was assumed to be $0 \%$ because $\delta^{65} \mathrm{Cu}$ values are $\sim 0 \%$ for rainwater, leachable fractions of marine aerosols ${ }^{11}$ and loess ${ }^{17}$. It was assumed that the $\delta^{65} \mathrm{Cu}$ of sinking particles (of mainly biogenic origin) from surface water was the same as the $\delta^{65} \mathrm{Cu}$ of

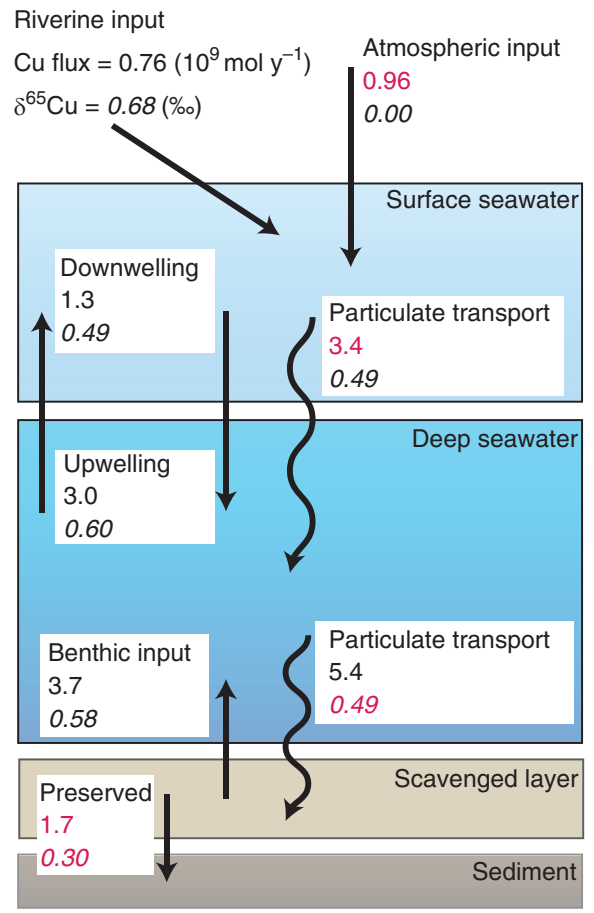

Figure 6 | Box model for $\mathrm{Cu}$ cycling in the ocean based on both elemental concentration and isotopic ratio. The Roman and italic values below the process names represent $\mathrm{Cu}$ flux in units of $10^{9} \mathrm{~mol} \mathrm{yr}^{-1}$ and $\delta^{65} \mathrm{Cu}$ values in \%, respectively. Black figures indicate observed values and magenta figures indicate values calculated based on mass balance.

ambient surface seawater (that is, $0.49 \%$ ), because isotopic fractionation during phytoplankton uptake and adsorption onto phytoplankton surface is expected to be insignificant, as described above. The $\delta^{65} \mathrm{Cu}$ of the benthic flux from the scavenged layer to deep seawater was assumed to be the global average of $0.58 \%$. This value is the average of $\delta^{65} \mathrm{Cu}$ in seawater samples nearest the bottom of the ocean. The unknown $\mathrm{Cu}$ fluxes that were calculated by this model are those of supply from the atmosphere, transport by sinking particles from the surface, preservation in sediments and return from the scavenged layer to deep water. The unknown $\delta^{65} \mathrm{Cu}$ values calculated by this model are those of the transporting flux by sinking particles in deep water and the preserved flux into sediments.

\section{Discussion}

From our data we infer that the $\delta^{65} \mathrm{Cu}$ values in surface seawater are mainly controlled by supply from rivers, the atmosphere and deep seawater. Biological uptake does not appear to cause significant isotopic fractionation of $\mathrm{Cu}$ in the open ocean. $\delta^{65} \mathrm{Cu}$ values in deep seawater are heavier than those in surface seawater and become heavier with the age of deep seawater, likely due to preferential scavenging of the light isotope $\left({ }^{63} \mathrm{Cu}\right)$.

Biological fractionation of $\mathrm{Cu}$ isotopes has not yet been sufficiently elucidated in the literature. There are only a few studies concerning isotopic fractionation of $\mathrm{Cu}$ by phytoplankton. Laboratory experiments have shown that uptake by several diatoms caused no significant fractionation or slight enrichment of the heavy $\mathrm{Cu}$ isotope $\left({ }^{65} \mathrm{Cu}\right)$ when the initial $\mathrm{Cu}$ concentration was $\sim 200 \mathrm{nmoll}^{-1}$ (ref. 26). However, a geochemical study in the Garonne River suggested that diatom species prefer the light $\mathrm{Cu}$ isotope $\left({ }^{63} \mathrm{Cu}\right)^{27}$. Thus, it is necessary to determine the $\delta^{65} \mathrm{Cu}$ of natural phytoplankton in the open ocean in future work.

We suggest that Fe-Mn oxides may be a major sink of $\mathrm{Cu}$ in the oxic ocean. $\delta^{65} \mathrm{Cu}$ values of Fe-Mn nodules are $0.33 \pm 0.23 \%$ 
(average \pm 2 s.d., $n=14)$ in the Pacific, $0.25 \pm 0.26 \%$ o $(n=8)$ in the Atlantic and $0.31 \pm 0.23 \%(n=31)$ in the world's oceans collectively ${ }^{10}$; the $\delta^{65} \mathrm{Cu}$ values of Fe-Mn crusts are $0.54 \pm 0.07 \%$ $(n=8)$ in the Pacific, $0.33 \pm 0.15 \%$ o $(n=8)$ in the Atlantic and $0.44 \pm 0.23 \%$ o $(n=16)$ in major ocean basins collectively ${ }^{11}$. Thus, $\delta^{65} \mathrm{Cu}$ of $\mathrm{Fe}-\mathrm{Mn}$ crusts and nodules is lighter than that of dissolved $\mathrm{Cu}$ in the ocean. Furthermore, the $\delta^{65} \mathrm{Cu}$ of $\mathrm{Fe}-\mathrm{Mn}$ crusts is significantly heavier in the Pacific than in the Atlantic $(P=0.01)$. These data are consistent with preferential scavenging of ${ }^{63} \mathrm{Cu}$ and gradual accumulation of ${ }^{65} \mathrm{Cu}$ in seawater via global ocean circulation. This view, however, seems contrary to experimental results on adsorption of $\mathrm{Cu}$ isotopes on $\mathrm{Fe}$ oxyhydroxides $^{26,28}$, which indicate enrichment of the heavy $\mathrm{Cu}$ isotope onto oxide surfaces in $\mathrm{NaNO}_{3}$ solutions or mixtures of acidic drainage and river water. The discrepancy may be caused by differences in conditions, such as $\mathrm{pH}, \mathrm{Cu}$ concentration and organic ligand concentration, between experimental solutions and natural seawater. In addition, it has been reported that $\mathrm{Cu}$ is associated with $\mathrm{Mn}$ and not $\mathrm{Fe}$ in $\mathrm{Fe}-\mathrm{Mn}$ crusts $^{29}$. Isotopic fractionation between free $\mathrm{Cu}$ and organic ligand-bound $\mathrm{Cu}$ could also be important for $\mathrm{Cu}$ isotopes in seawater, because $\mathrm{Cu}$ is mostly complexed with organic ligands. In a laboratory experiment, humic acid preferentially formed complexes with the heavy $\mathrm{Cu}$ isotope $\mathrm{e}^{30}$. It is therefore likely that the complexation of $\mathrm{Cu}$ with dissolved organic ligands in seawater also causes mass fractionation of $\mathrm{Cu}$, because the organic ligands and humic acid most likely have the same functional groups. Furthermore, $\mathrm{Cu}$ is contained not only in the Fe-Mn oxide fraction but also in the organic fraction of sinking particles ${ }^{31,32}$. Thus, understanding isotopic fractionation during scavenging of dissolved $\mathrm{Cu}$ from seawater is not straightforward. It was originally proposed in a previous field study of rivers and oceans that there is equilibrium partitioning of isotopes between heavy $\mathrm{Cu}$ bound to organic ligands in the dissolved phase and light $\mathrm{Cu}$ adsorbed to particles ${ }^{8}$. This hypothesis is consistent with our explanation of light $\mathrm{Cu}$ scavenging.

In the box model using both the $\mathrm{Cu}$ concentration and $\delta^{65} \mathrm{Cu}$ (Fig. 6), we constrained the transporting flux of $\mathrm{Cu}$ from surface to deep water by sinking particles to be $3.4 \times 10^{9} \mathrm{~mol} \mathrm{yr}^{-1}$. The residence time for dissolved $\mathrm{Cu}$ in surface water $(<100 \mathrm{~m})$ is $\sim 9$ years, which is consistent with previous estimates of $3.2-11.7$ years ${ }^{5,33}$. The calculated preservation flux of $\mathrm{Cu}$ into sediments is $1.7 \times 10^{8} \mathrm{~mol} \mathrm{yr}^{-1}$. The overall residence time of $\mathrm{Cu}$ in the ocean is calculated by dividing the average concentration by the preservation flux. Our estimate of the overall residence time of $\mathrm{Cu}$ is 2,000 years, which is within the range of literature values $(1,700-6,400 \text { years })^{4,11}$. The calculated $\delta^{65} \mathrm{Cu}$ of preserved $\mathrm{Cu}$ in sediments is $+0.30 \%$, which is quite similar to the averages reported for Fe-Mn oxides ${ }^{10,11}$

We constrained the atmospheric input of dissolved $\mathrm{Cu}$ to be $9.6 \times 10^{8} \mathrm{~mol} \mathrm{yr}^{-1}$. Our model suggests that the present atmospheric input of $\mathrm{Cu}$ is comparable to the riverine input. A significant correlation was found between $\mathrm{Cu}$ and ${ }^{210} \mathrm{~Pb}$ in surface seawater, implying a strong atmospheric supply of $\mathrm{Cu}$, as ${ }^{210} \mathrm{~Pb}$ is a tracer for atmospheric input ${ }^{4}$. Boyle et al. ${ }^{4}$ estimated both the atmospheric and riverine $\mathrm{Cu}$ input to be $6.0 \times 10^{8} \mathrm{~mol} \mathrm{yr}^{-1}$, which is similar to our results. However, our value is significantly larger than the natural atmospheric input previously estimated at $5.4 \times 10^{7} \mathrm{molyr}^{-1}$, which was obtained by multiplying the total dust flux by the mean crustal $\mathrm{Cu}$ concentration and solubility ${ }^{11}$.

Two possible explanations are given to rationalize this difference. First, it is possible that the $\mathrm{Cu}$ concentration and solubility in marine aerosols would be different from those in the continental crust. The enrichment factor of $\mathrm{Cu}$ relative to $\mathrm{Al}$ in marine aerosols varies over a large range of 1-200 compared with the continental crust ${ }^{25}$. The solubility of $\mathrm{Cu}$ in aerosols has a wide range of $15-86 \%$ (ref. 34). It has been suggested that the enriched and soluble $\mathrm{Cu}$ in aerosols are from anthropogenic sources ${ }^{34-36}$. However, Maring et al. evaluated the source of $\mathrm{Cu}$ enrichment in aerosols near Enewetak in the North Pacific, suggesting that atmospheric soluble $\mathrm{Cu}$ is from primary natural origins and that soil organic matter enriched in $\mathrm{Cu}$ could be a significant source of soluble $\mathrm{Cu}^{37}$. If anthropogenic $\mathrm{Cu}$ has significantly affected atmospheric input as we estimate, then the steady-state assumption is imperfect for the modern ocean, because anthropogenic inputs would have substantially increased in the recent $\sim 100$ years, whereas the overall oceanic residence time of $\mathrm{Cu}$ is thousands of years. Second, other fluxes to the open ocean surface may have an effect. One possible flux is from the continental shelf sediment, where a portion of $\mathrm{Cu}$ is derived from the reduction of primary terrigenous metal oxides ${ }^{38}$. The $\delta^{65} \mathrm{Cu}$ value of this flux would also be close to the crustal value $(0 \%$ o) and lighter than that of surface seawater. If these fluxes are included in our box model, then our estimate of atmospheric input may decrease. As described above, some uncertainties remain in our box model. Our results, however, confirm possibilities of this new box model based on both concentration and isotopic composition of trace metals.

\section{Methods}

Seawater samples. The South Indian and North Pacific seawater samples were collected during the R/V Hakuho-maru cruises KH 09-4, KH 10-2, KH 11-7 and $\mathrm{KH} 12-4$ using a clean sampling system ${ }^{14}$. In a clean booth, seawater was filtered through a $0.2-\mu \mathrm{m}$ cartridge filter (Acro pak, Pall), acidified with $\mathrm{HCl}$ to $\mathrm{pH} 1.7-2.2$, and stored in 2-l or 4-1 LDPE bottles (Nalgene bottle, Thermo Fisher Scientific) or 6-1 LDPE cubic bags (Lontainer, Sekisui Seikei), which were pre-cleaned by overnight treatment with $4 \mathrm{M} \mathrm{HCl}$ followed by rinsing with deionized water. The North Atlantic sample was a GEOTRACES reference material collected at BATS during the US-GEOTRACES KN193-5 cruise of the R/V Knorr. The South Atlantic sample was collected at Station 3 during the UK-GEOTRACES D357 cruise of the RSS Discovery.

Rainwater samples. Rainwater was collected from two sites using pre-cleaned polyethylene funnels and cubic bags (Lontainer) or 2-1 LDPE bottles. One site was on the roof of the main building of the Institute for Chemical Research, which is located in an urban area of Honshu Island, Japan. The other site was on top of Mt. Kajigamori, which is located in a rural area of Shikoku Island. Rainwater samples were filtered through a $0.22-\mu \mathrm{m}$ filter (Millipore) and acidified with $\mathrm{HCl}$ to $\mathrm{pH}$ $1.7-2.1$.

Analytical procedure of $\delta^{65} \mathbf{C u}$ and $\mathbf{C u}$. Copper concentration and isotopic composition were determined as described in a previous paper ${ }^{12}$. Briefly, $\mathrm{Cu}$ in seawater or rainwater was collected using a column of Nobias chelate PA-1 resin (Hitachi High Technologies) followed by elution with $1 \mathrm{M} \mathrm{HNO}_{3}$. The eluate was evaporated to dryness, and the residue was re-dissolved with $10 \mathrm{M} \mathrm{HCl}$. The sample was passed through a column of anion exchange resin (AG MP-1, Bio-Rad); additional $10 \mathrm{M} \mathrm{HCl}$ was then passed through the column to remove co-existing elements, followed by the elution of $\mathrm{Cu}$ with $5 \mathrm{M} \mathrm{HCl}$. This eluate was evaporated to dryness and the residue was re-dissolved with $1 \mathrm{M} \mathrm{HNO}_{3}$. Finally, the $1 \mathrm{M}$ $\mathrm{HNO}_{3}$ solution was re-evaporated and the residue was re-dissolved with $0.4 \mathrm{M}$ $\mathrm{HNO}_{3}$, yielding the pre-concentrated sample. One hundred micrograms of the preconcentrated sample was diluted with $0.4 \mathrm{M} \mathrm{HNO}_{3}$ by a factor of $\sim 10$ and used for measurement of $\mathrm{Cu}$ concentration. Co-existing $\mathrm{Na}, \mathrm{Mg}, \mathrm{Ba}, \mathrm{Ni}, \mathrm{Zn}, \mathrm{Cr}$ and $\mathrm{Ti}$ were also measured to ascertain whether these interfering elements possessed concentrations sufficiently low to permit accurate $\mathrm{Cu}$ isotopic measurements. When the $\mathrm{Na}$ (p.p.b.)/Cu (p.p.b.) ratio in the pre-concentrated sample was higher than 1, the solution was not used for discussion. For the $\mathrm{Cu}$ isotopic measurement, which used a multicollector ICP-MS (Thermo Finnigan Neptune or Neptune Plus, Thermo Fisher Scientific), the final solution was diluted to adjust the $\mathrm{Cu}$ concentration to 50 p.p.b. and $\mathrm{Zn}$ was added to give a solution of 100 p.p.b. for external normalization. The precision of this method was evaluated previously by repeated analyses of coastal seawater to be $\pm 0.07 \%$ o $( \pm 2 \text { s.d., } n=6)^{12}$. In this study, 34 samples were each divided into two aliquots and analysed in duplicate, resulting in an average 2 s.d. of $0.045 \%(n=34)$ for $\delta^{65} \mathrm{Cu}$ and $0.11 \mathrm{nmol} \mathrm{kg}^{-1}$ $(n=34)$ for $\mathrm{Cu}$ concentration. These values are shown as error bars in the figures. 


\section{References}

1. Brand, L. E., Sunda, W. G. \& Guillard, R. R. L. Reduction of marine phytoplankton reproduction rates by copper and cadmium. J. Exp. Biol. Ecol 96, 225-250 (1986)

2. Coale, K. H. \& Bruland, K. W. Copper complexation in the Northeast Pacific. Limnol. Oceanogr. 33, 1084-1101 (1988).

3. Bruland, K. W. \& Lohan, M. C. in Treatise on Geochemistry (eds Holland, H. D. \& Turekian, K. K.) (Elsevier, 2003).

4. Boyle, E. A., Sclater, F. R. \& Edmond, J. M. The distribution of dissolved copper in the Pacific. Earth Planet. Sci. Lett. 37, 38-54 (1977).

5. Bruland, K. W. Oceanographic distributions of cadmium, zinc, nickel, and copper in the North Pacific. Earth Planet. Sci. Lett. 47, 176-198 (1980).

6. Boyle, E. A. et al. GEOTRACES IC1 (BATS) contamination-prone trace element isotopes $\mathrm{Cd}, \mathrm{Fe}, \mathrm{Pb}, \mathrm{Zn}, \mathrm{Cu}$, and $\mathrm{Mo}$ intercalibration. Limnol. Oceanogr. Methods 10, 653-665 (2012).

7. Bermin, J., Vance, D., Archer, C. \& Statham, P. J. The determination of the isotopic composition of $\mathrm{Cu}$ and $\mathrm{Zn}$ in seawater. Chem. Geol. 226, 280-297 (2006).

8. Vance, D. et al. The copper isotope geochemistry of rivers and the oceans. Earth Planet. Sci. Lett. 274, 204-213 (2008).

9. Thompson, C. M., Ellwood, M. J. \& Wille, M. A solvent extraction technique for the isotopic measurement of dissolved copper in seawater. Anal. Chim. Acta 775, 106-113 (2013).

10. Albarède, F. in Geochemistry of Non-Traditional Stable Isotopes (eds Johnson, C. M., Beard, B. L. \& Albarède, F.) (Mineralogical Society of America, 2004)

11. Little, S. H., Vance, D., Walker-Brown, C. \& Landing, W. M. The oceanic mass balance of copper and zinc isotopes, investigated by analysis of their inputs, and outputs to ferromanganese oxide sediments. Geochim. Cosmochim. Acta 125, 673-693 (2014).

12. Takano, S., Tanimizu, M., Hirata, T. \& Sohrin, Y. Determination of isotopic composition of dissolved copper in seawater by multi-collector inductively coupled plasma mass spectrometry after pre-concentration using an ethylenediaminetriacetic acid chelating resin. Anal. Chim. Acta 784, 33-41 (2013).

13. Schlitzer, R. Ocean Data View. http://www.awi-bremerhaven.de/GEO/ODV (2002).

14. Vu, H. T. D. \& Sohrin, Y. Diverse stoichiometry of dissolved trace metals in the Indian Ocean. Sci. Rep 3, 1745 (2013).

15. Zhao, Y., Vance, D., Abouchami, W. \& de Baar, H. J. W. Biogeochemical cycling of zinc and its isotopes in the Southern Ocean. Geochim. Cosmochim. Acta 125, 653-672 (2014).

16. Lupton, J. Hydrothermal helium plumes in the Pacific Ocean. J. Geophys. Res. 103, 15853-15868 (1998).

17. Li, W., Jackson, S. E., Pearson, N. J., Alard, O. \& Chappell, B. W. The $\mathrm{Cu}$ isotopic signature of granites from the Lachlan Fold Belt, SE Australia. Chem. Geol. 258, 38-49 (2009).

18. Abouchami, W. et al. Biogeochemical cycling of cadmium isotopes in the Southern Ocean along the Zero Meridian. Geochim. Cosmochim. Acta 127, 348-367 (2014)

19. Ripperger, S., Rehkämper, M., Porcelli, D. \& Halliday, A. N. Cadmium isotope fractionation in seawater-A signature of biological activity. Earth Planet. Sci. Lett. 261, 670-684 (2007).

20. Xue, Z. et al. Cadmium isotope variations in the Southern Ocean. Earth Planet. Sci. Lett. 382, 161-172 (2013).

21. Abouchami, W. et al. Modulation of the Southern Ocean cadmium isotope signature by ocean circulation and primary productivity. Earth Planet. Sci. Lett. 305, 83-91 (2011).

22. Chester, R., Thomas, A., Lin, F. J., Basaham, A. S. \& Jacinto, G. The solid state speciation of copper in surface water particulates and oceanic sediments. Mar. Chem. 24, 261-292 (1988).

23. Sarmiento, J. L. Ocean Biogeochemical Dynamics (Princeton University Press, 2006).

24. Gaillardet, J., Viers, J. \& Dupré, B. in Treatise on Geochemistry (eds Holland, H. D. \& Turekian, K. K.) (Elsevier, 2003).

25. Chester, R. \& Jickells, T. Marine Geochemistry (Willey-Blackwell, 2012).

26. Pokrovsky, O. S., Viers, J., Emnova, E. E., Kompantseva, E. I. \& Freydier, R. Copper isotope fractionation during its interaction with soil and aquatic microorganisms and metal oxy(hydr)oxides: Possible structural control Geochim. Cosmochim. Acta 72, 1742-1757 (2008).

27. Petit, J. C. J. et al. Anthropogenic sources and biogeochemical reactivity of particulate and dissolved $\mathrm{Cu}$ isotopes in the turbidity gradient of the Garonne River (France). Chem. Geol. 359, 125-135 (2013).

28. Balistrieri, L. S., Borrok, D. M., Wanty, R. B. \& Ridley, W. I. Fractionation of Cu and $\mathrm{Zn}$ isotopes during adsorption onto amorphous $\mathrm{Fe}(\mathrm{III})$ oxyhydroxide: Experimental mixing of acid rock drainage and ambient river water. Geochim. Cosmochim. Acta 72, 311-328 (2008).

29. Little, S. H., Sherman, D. M., Vance, D. \& Hein, J. R. Molecular controls on $\mathrm{Cu}$ and $\mathrm{Zn}$ isotopic fractionation in Fe-Mn crusts. Earth Planet. Sci. Lett. 396, 213-222 (2014).

30. Bigalke, M., Weyer, S. \& Wilcke, W. Copper isotope fractionation during complexation with insolubilized humic acid. Environ. Sci. Technol. 44, 5496-5502 (2010).

31. Fischer, K., Dymond, J., Lyle, M., Soutar, A. \& Rau, S. The benthic cycle of copper: Evidence from sediment trap experiments in the eastern tropical North Pacific Ocean. Geochim. Cosmochim. Acta 50, 1535-1543 (1986).

32. Noriki, S., Shiribiki, T., Yokomizo, H., Harada, K. \& Tsunogai, S. Copper and nickel in settling particle collected with sediment trap in the western North Pacific. Geochem. J. 31, 373-382 (1997).

33. Helmers, E. \& Schrems, O. Wet deposition of metals to the tropical North and the South Atlantic ocean. Atmos. Environ. 29, 2475-2484 (1995).

34. Duce, R. A. et al. The atmospheric input of trace species to the world ocean. Global Biogeochem. Cycles 5, 193-259 (1991).

35. Arimoto, R. et al. Concentrations, sources, and fluxes of trace elements in the remote marine atmosphere of New Zealand. J. Geophys. Res. Atmos. 95, 22389-22405 (1990)

36. Desboeufs, K. V., Sofikitis, A., Losno, R., Colin, J. L. \& Ausset, P. Dissolution and solubility of trace metals from natural and anthropogenic aerosol particulate matter. Chemosphere 58, 195-203 (2005).

37. Maring, H. B. \& Duce, R. A. The impact of atmospheric aerosols on trace metal chemistry in open ocean surface seawater: 2. Copper. J. Geophys. Res. 94, 1039-1045 (1989).

38. Boyle, E. A., Huested, S. S. \& Jones, S. P. On the distribution of copper, nickel, and cadmium in the surface waters of the North Atlantic and North Pacific Ocean. J. Geophys. Res. 86, 8048-8066 (1981).

\section{Acknowledgements}

We thank Susan Little, Corey Archer and Derek Vance (ETH, Zurich) for performing intercalibration with us and providing the South Atlantic sample. We also thank the officers and crew of the R/V Hakuho-Maru for their assistance in obtaining samples and Shoji Imai (the University of Tokushima) for sampling rainwater at the top of Mt. Kajigamori. We are grateful to Takanori Nakano and Kichoel Shin (Research Institute for Humanity and Nature) for their help with the MC-ICP-MS measurements. This work was supported by funds from the Steel Industry Foundation for the Advancement of Environmental Protection Technology and by grants-in-aid from the Japanese Society for the Promotion of Science.

\section{Author contributions}

S.T. and Y.S. designed the research. S.T. determined the concentration of $\mathrm{Cu}$ and $\delta^{65} \mathrm{Cu}$ M.T. contributed to measurements with MC-ICP-MS. T.H. helped with the development of the analytical method and supplied the standard reference material of $\mathrm{Cu}$ (NIST SRM 976). All authors contributed to the interpretation of the data and preparation of the manuscript.

\section{Additional information}

Supplementary Information accompanies this paper at http://www.nature.com/ naturecommunications

Competing financial interests: The authors declare no competing financial interests.

Reprints and permission information is available online at http://npg.nature.com/ reprintsandpermissions/

How to cite this article: Takano, S. et al. Isotopic constraints on biogeochemical cycling of copper in the ocean. Nat. Commun. 5:5663 doi: 10.1038/ncomms6663 (2014). 